\begin{tabular}{l} 
RCCS \\
\hline Annual Review
\end{tabular}

\section{RCCS Annual Review}

A selection from the Portuguese journal Revista Crítica de Ciências Sociais

$3 \mid 2011$

Issue no. 3

\title{
Participatory Budgeting and the Use of Information and Communication Technologies: A Virtuous Cycle?
}

Eleonora S. M. Cunha, Giovanni Allegretti and Marisa Matias

Translator. Sheena Caldwell

\section{OpenEdition}

\section{Journals}

Electronic version

URL: http://journals.openedition.org/rccsar/316

DOI: $10.4000 /$ rccsar.316

ISSN: $1647-3175$

\section{Publisher}

Centro de Estudos Sociais da Universidade de Coimbra

\section{Electronic reference}

Eleonora S. M. Cunha, Giovanni Allegretti and Marisa Matias, «Participatory Budgeting and the Use of Information and Communication Technologies: A Virtuous Cycle? », RCCS Annual Review [Online],

3 | 2011, Online since 01 October 2011, connection on 19 April 2019. URL : http://

journals.openedition.org/rccsar/316; DOI : 10.4000/rccsar.316 
Eleonora S. M. Cunha, Giovanni Allegretti, Marisa Matias

Center for Social Studies, University of Coimbra, Portugal

\title{
Participatory Budgeting and the Use of Information and Communication Technologies: A Virtuous Cycle? ${ }^{1}$
}

\begin{abstract}
This text discusses whether the use of Information and Communication Technologies (ICT) in Participatory Budgeting processes can promote more engaged forms of citizenship and democracy. The discussion is based on the analysis of a few examples from different countries, which show how the use of ICTs is framed by institutions. The inclusion of ICT in participation and decision-making processes can assume very different shapes. In some cases, they can be used within well-defined limits, as information tools or for monitoring the PB during the debate and the implementation phase; in other cases, a more advanced use of ICT potentialities can serve as support to political decision-making processes. The different examples presented in the text represent the different configurations that exist in the ambit of both "subordinate" and "coordinated" models of ICT use within democratic processes.
\end{abstract}

Keywords: political action; Participatory Budgeting (PB); participatory processes; Information and Communication Technologies (ICT).

\section{Introduction}

Since the mid twentieth century the consolidation of democracy as a political regime in Western societies has been increasingly accompanied by different democratic practices. Many of these have aimed to reverse processes that have gradually established a separation between politics and citizens by providing scope for direct democracy or investing in a combination of this and the work of representative institutions, which - through mutual support - can reinforce both in the face of the predominance of the market, which also affects most decision-making in public life. The mechanisms created have sought to respond adequately to crises in governance that translate into crises of confidence in the strategies and legitimacy of the state. Within this context, countless forms of democratic experimentation or 'technologies of participation' (Nunes, 2006) have been developed. One consequence of these new forms of citizen participation associated with projects traditionally directed by the state - which at a particular period in history became the

\footnotetext{
${ }^{1}$ Article published in RCCS 91 (December 2010). This text is an amended and shortened version of a paper presented at the colloquium "Changing politics through digital networks: The role of ICTs in the formation of new social and political actors and actions," Florence, 5-6 October 2007. We would particularly like to thank Claudino Ferreira (who offered ideas for the revision of the text) and Boaventura de Sousa Santos, João Arriscado Nunes, Ana Raquel Matos and Daniel Neves from the Center for Social Studies who shared their interest in studying PB processes with us and whose work has inspired us.
} 
Welfare State in the North and the Developmental State in the South - was a receptiveness to experiments in citizen intervention and organisation "supported by the mobilisation of practical know-how and the construction of a form of knowledge guided by prudence and attention to the consequences of actions" (id.).

In the meantime, the development and diversification of information and communication technologies (ICT) led to the expansion of the so-called 'information society', posing a new set of questions and challenges for politics, ranging from the emergence of new identity and interest groups to new forms of political action linked to several different social and political actors.

The possibility of linking this deepening of democracy to the development of new technologies led (in extreme situations) to the creation of the paradigm of electronic democracy (e-democracy), ${ }^{2}$ whose ontology may be considered only apparently different (Addison and Heshmati, 2003; Horrocks and Prachett, n.d.) to the extent that its designs are influenced by different concepts of democracy, but is not ontologically different in any other way from the democratic paradigm.

The debate on the effects and potential of this association has been related to two major sets of expectations. On the one hand, there are the positive expectations emerging from the potential which the interrelationship between democracy and ICT evinces for the distribution of power, by extending democratic participation to a kind of 'virtual public sphere', as well as the possibility of increasing government transparency and its control by citizens. On the other hand, there are growing negative expectations resulting from the realisation that very often, instead of helping to redistribute power, e-democracy results in a stronger concentration of power in the hands of a few institutions, reinforcing market predominance or the centrality of the state to the detriment of the other actors in the political system and in society (Hacker and Djik, 2000).

\footnotetext{
${ }^{2}$ Electronic democracy is understood by the authors of this article to be the set of democratic processes that provide for citizen participation, through the use of information and communication technologies, in fundamental issues associated with governance, decision-making processes within the state and the state's relationship with citizens. It differs from electronic government (e-government), which refers to the use by governments of information and communication technologies as part of their efforts to modernise and rationalise the public services they provide to users by improving quality, reducing costs and offering services that cannot be provided using traditional models (Bannister and Walsh, 2002; Ring and Walden, 2003; Deiber, 2003; Graft and Svensson, 2006). A common feature of both concepts is the value they place on processes that make information available to members of the community.
} 
Taking as a departure point the contradictions emerging out of a number of innovative experiments linking representative democracy and participatory democracy, this article aims, above all, to analyse certain aspects of this ambivalent relationship at a time when the challenges generated by broadening the various means of communication and creating new potential arenas for political participation extending beyond the traditional 'formal' processes must be added to these relationships. More specifically, it focuses on an innovative form of building new relations between representative democracy, participatory democracy and new technologies which has become prominent, acquiring its own status within the framework of institutional experimentation, namely Participatory Budgeting (PB). This choice is derived from the fact that PB is a tool that is currently attracting growing interest (particularly in a time of economic crisis affecting many democracies in the world), and also because it has the nature of a "clear and recognisable technical mechanism" by being associated with a highly complex technical tool, namely the budget and the main options it contains.

As relations between the state and civil society tend to be characterised by the principle of "double delegation" (Callon et al., 2001) - which translates into a separation between specialists and the lay public, and between representation and participation - experiences of PB are a clear example of how strong social mobilisation and the convergence of political projects associated with the state and with civil society (Dagnino, Olvera and Panfichi, 2006) allow democratic processes to be devised which link representation and participation and, at the same time, create spaces for the empowerment and involvement of citizens in areas traditionally considered the "preserve of experts."

The article starts by briefly contextualising PB experiments within the arena of debates on the deepening of democracy, and more specifically the association between democracy, technology and participation. Then, based on some examples, it describes the experience of the gradually deepening relationship between $\mathrm{PB}$ and the use of ICT, providing the concrete elements of a model of relational grammar which tends to 'subordinate' the use of technology to the building of new arenas for public decision-making that focus on the physical co-presence of the different actors involved. Finally, it presents some reflections and challenges for the reformulation of the inter-relationship between new technologies and the broader experiences of mass participation in building public policies for transforming and managing territories. 


\section{Democracy, participation and the use of new technologies within the context of Participatory Budgeting}

It is more difficult nowadays to unequivocally place forms of PB - as instruments for political innovation - within the context of the six models of democracy proposed by Held (2006) than it must have been in the early 1990s when the first experiments took shape in Brazil within a highly tense scenario associated with the democratisation of local government centring on citizen involvement in public decision-making and the idea of the constructive contribution of the 'local' in reformulating national and global strategies. Held's classification includes the construction of "model types" of democracy, defined as legal, competitive, pluralist, participatory, libertarian and plebiscitary. The three latter models may be included in what Santos and Avritzer (2002) term "high intensity democracies." In particular after the 'return of the caravels' (Allegretti \& Herzberg, 2004), that is, the phase of mass experimentation with PB (Cabannes, 2004) which extended the South-American example to more than 1,600 other cases in the American subcontinent, some cities in Africa and Asia and hundreds of municipalities in Europe (Sintomer, Herzberg \& Allegretti, 2010), unequivocally locating PB within one of these types is an even more daunting task, although it is clear, in most cases, that PB tends to fit into 'high intensity' democratic concepts.

This is due to the fact that PB constitutes a hub that is becoming increasingly essential to other experiences of participation, but does not have any monopoly over experiments in innovative citizen participation processes involving public decision-making. On the contrary, it tends to be infected by, and blend into, other experiences, diluting its original features, adopting different, consolidated techniques and thus affirming itself in the collective imagination as a 'meta-model', adaptable to different concepts of democracy which shape numerous practices (Bobbio, 2006; Allegretti and Secchi, 2007; Chavez, 2007). The variety of political horizons serving as reference points, together with the overall and specific objectives underpinning many PB practices, is particularly evident in Europe, as shown by Sintomer, Herzberg and Röcke (2005) and Sintomer and Allegretti (2009), evincing, on a motivational level, new "model types" for PB that are related to forms of neo-corporativism or aim to construct 'participatory democracy', 'participatory modernisation of the public administration apparatus', or simply 'proximity democracy' or 'community development'.

Adding a new variable (such as the relationship between participatory processes and ICT) to these diverse uses and forms of PB within the different concepts of 'grand democracy' (to 
employ a definition widely used in Scandinavian Europe) might - theoretically - complicate the modelling of these processes. However, experience tells us that in many cases the use of ICT does not determine new hybrid configurations of $\mathrm{PB}$, but tends to reinforce the main interpretation of each experience.

From this point of view, it is worth referring to Hacker and Djik's study (2000). For these authors, the main democratic goals to be achieved with the support of ICT relate to the six models of democracy proposed by Held, including the objectives and strategies for their use. According to the authors, 'legal democracy' allows for the use of ICT as a means of supplying more and better information to governments, administrators, representatives, and citizens with a view to fostering effectiveness and efficiency, as well as greater transparency in the political system. The aim of using ICT from the perspective of 'competitive democracy' is to strengthen the position of governments, politicians and administrators (as in general election campaigns). In 'pluralist democracy' models, the main goal appears to be that of supporting applications that strengthen information and communications within and between civil society organisations. PB experiences appear to be well represented in terms of ICT use in the 'participatory democracy' models proposed by Hacker and Djik, in which ICTs are used mainly to educate and mobilise citizens through processes that shape collective opinion in debates and educational settings. This includes computerised information campaigns, mass public information systems, provision of easy access to users, electronic debates to mould opinions, active learning and participation. The 'libertarian' conception of democracy extends virtual communities and horizontal communication in collectively created networks and, to this end, citizens must be kept up-to-date by advanced, free information systems, providing them with the conditions to voice opinions and to vote. Finally, in the 'plebiscitary model' of democracy, ICTs are seen as communication channels that amplify the voices of citizens, breaking down the barriers to direct democracy in complex societies.

In this interpretation it seems clear that there is an increasing democratisation in the use of ICTs in the various democratic arenas, configuring something parallel to the "ladder of participation" described by Sherry Arnstein (1969). Certain 'steps' in the ladder (such as the one relating to the centrality of information) are configured less as isolated situations (or models in themselves) and more as pre-conditions integral to the other levels of participatory content. 
In addition to identifying objectives and strategies for the use of ICT in relation to models of democracy, Hacker and Djik (2000) have also proposed two sets of concepts that contain an element of assessment of the relationship between power and social actors which are useful in a political analysis of the use of technologies. The first deals with information traffic' patterns and aims to show who holds power over information. Thus, 'allocution' is used when a central actor provides information to several units; 'consultation', when a central actor opens information systems to public consultation; 'registration', when a central actor gathers information; and 'conversation' when information is exchanged between different types of actors. The second set refers to the level of interactivity of communication. Hacker and Djik discuss the importance of individualising the 'spatial dimension' (two-way communication, involving action and reaction), the 'temporal dimension' (synchronic communication), the 'action dimension' (the degree of control exerted by actors over communication and the possibility of exchanging roles according to the time and content of communication), and the 'contextual and mental dimension' (the intelligibility of contexts and shared understanding). The latter appears to be the only level that symmetrically combines face-to-face interaction with the use of ICT.

Up to now, most forms of PB (including those in countries such as Sweden, where the high level of broadband penetration can lead to hypotheses that focus more on the use of technologies) have tended to favour spaces offering direct contact between local residents and between them and their representatives (politicians and technicians) in the institutional sphere. There are several reasons for this, the first being the fear that the distance between citizens and a seemingly "cold and technocratic" subject may be heightened by the use of electronic technologies. Thus, the general worldwide scenario for PB has favoured the construction of spaces for face-to-face encounters, with the aim of reinforcing social ties and relationships between administrators and local residents that have been curtailed or made difficult. These "warm" spaces have proved extremely positive in the construction of a social pedagogy (Schmidt, 2000) and a negotiated solidarity (Abers, 2000), also in cases in which the concrete results have not differed greatly from those that would have resulted from the traditional exercise of power delegated to competent administrators (Ravazzi, 2007).

Within this general framework, the "grammar" of relations between PB and ICTs has favoured a 'subordinate' position for technologies, given the possibility of wasting energy and (human and economic) resources on creating "warm" interactive methods between 
territorial actors. Viewed as a 'cold medium' for interaction (on a similar level to referenda, questionnaires or telephone surveys), ICT has been relegated to second place in many participatory processes and its proposals subsequently submitted to control by face-to-face meetings. ${ }^{3}$ This has also occurred in situations (Borghi, 2005) where ICT use was explicitly evaluated as a factor in the social inclusion of individuals or groups (commuters, families residing far from the centre where meetings are held, the sick or those with restricted mobility) who cannot attend public meetings, as in the case of Parma or Modena in Italy. In the latter, a pilot project, UnoX1, was incorporated into the municipal electronic information system, providing on-line streaming for some meetings in 2006, and even pauses for contributions and suggestions that could later be submitted to the ongoing live debate in the main PB headquarters.

The assessment of the new spaces to be constructed to accompany the series of debates arising out of $\mathrm{PB}$ has been much more important than reflection on the timing of this interaction, although this has meant extending participation to cover the whole year (from January to December) or sacrificing the depth of the technical assessments of the feasibility of proposals submitted by local residents in cases where the PB cycle was limited to the second half of the year. ITC was therefore hardly ever evaluated in terms of its immediacy (and capacity to modify the significance of the time factor in proceedings), but was instead subordinated to the time periods dedicated to face-to-face debate developed in meetings, workshops, or by local theme-based working groups which characterise the majority of PB organisational architectures.

Only rarely has greater attention been paid to evaluating the potential of ICT, as in the case of Jun, a municipality of little more than 24,000 inhabitants in the Spanish province of Granada. Since 2001 all local families have been given support in the use of IT resources and purchasing computers for family use or using them in public areas with Internet access. This pre-condition has made it possible for voting on the Annual Budget at the Municipal Assembly plenary meeting to be almost simultaneous with citizen web-based voting. ${ }^{4}$ In this case, there are political reasons for the time lag between the two voting operations, since it aims to secure a final vote on the public documents (already voted for - on a consultative

\footnotetext{
${ }^{3}$ There are many examples of suggestions made by local residents via computerised means (e-mail or web pages with interactive files) being submitted for assessment at public meetings, as in the case of Veneza Lido, Pieve Emanuele or Grottamare, in Italy.

${ }^{4}$ See Ayuntamiento de Jun website (http://www.ayuntamientojun.org).
} 
basis - by the inhabitants) for those elected, thus acknowledging the importance of representative democracy.

Pilot schemes such as these aim to link the real-time components of PB processes to the use of ICT through a syntax based on 'coordinate sentences'. However, it would seem that they are difficult to reproduce on a larger scale, for practical and economic reasons. Nevertheless it is true that, although there are, as yet, no comparative analyses on the use of ICT in PB, there is a strong impression that the majority of experiments did not aim to construct virtual spaces in which the function of conversation between actors was ascribed to ICT, based on the acknowledgment of its capacity to stimulate the mental dimension of interchange and shared understanding.

\section{The importance of ICT in some evolving PB experiments}

One particularly interesting case - and a little unusual in terms of the overall scenario illustrating the relationship between ICT and PB is that of Belo Horizonte, the capital of Minas Gerais (Brazil). Having begun in 1993, PB in this city adopted various innovations in the institutional design of the process over the years, evincing significant changes in its "adaptive" nature, especially in terms of incorporating ICT into the ongoing reformulation of the political project. Since it was first designed, PB in Belo Horizonte has combined direct participation of citizens and association representatives in decision-making processes. For many years the Internet was used essentially as a means of providing information to the upper-middle classes, recognising that it would be necessary to invest in other means of direct communications for other local people, such as leaflets, caricatures and cartoons, street broadcasts, posters, and announcements on local radio. The content of the information provided via the Internet rarely had any importance in its own right independent of the series of live meetings that favoured oral communication. In 2006, however, a major change took place when the so-called "Digital PB" became associated with the process of public decision-making for the city budget, offering the possibility of choosing some investments via the Internet. These investments, worth 20 million reais, were directed towards macro-areas of the city viewed as a whole, thus partly removing the regionalised nature ${ }^{5}$ of the choices. The resource supplemented (rather than competed with) the funds

\footnotetext{
${ }^{5}$ In PB procedures in Brazil the urban districts into which the territory is divided are usually called "regions" to facilitate public debate in areas close to where citizens live. Comparative studies of PB emphasise the existence
} 
destined for the Regional PB (approximately 80 million reais). In order to implement the process, the Belo Horizonte City Council set up approximately 178 polling stations, including one on a bus which travelled around the most crowded areas (particularly in the poorer areas of the city where the digital divide is potentially much greater) and training was given to help those who used them to vote. In addition to voting, people could access various kinds of information on PB, take virtual visits to the building sites, participate in discussion and send electronic messages to the PB coordination team.

The opening up of an arena such as digital PB naturally led to a clear definition of the rules for participation, since it was open to all voters in the city. The Council preselected 36 projects for voting (4 for each region in the city), which had previously been voted on by the regional live PB delegates. Voters had the opportunity to choose one project for each region (a total of 9). In the first digital PB session, which lasted 42 days, 172,266 voters took part, casting a total of 503,266 votes. In the same year approximately 38,302 people took part in the live PB sessions. These two kinds of participation - in real-time PB meetings, and via the Internet in the case of the digital PB - were counted separately, operating as complementary processes.

The second edition of the Digital PB took place in 2008, with some changes to its original design. One initial change was to reduce the number of investments to five, concentrated more on transport bottlenecks rather than and on districts and involving a much greater number of beneficiaries. Much greater resources were reserved for the chosen project than had been allocated in the first edition (amounting to around 40 million), whilst investments for real-time PB remained at approximately 80 million. The number of voting stations was increased to 275 and the travelling bus was retained. Innovations in this campaign included the creation of two new interactive tools on the Digital PB webpage: five quick-post forums (one for each investment) and four chartrooms based on subjects predefined by the City Council in which citizens and members of the government team could participate. In addition, a free telephone line was made available for voting, in order to reach the population without access to the Internet. The voting period was shorter ( 26 days) and 
fewer people participated $(124,320), 90.76 \%$ of whom voted by Internet and $9.24 \%$ by telephone.

It is worth noting that in Lisbon (the first European capital to envisage a PB procedure that applied to the whole municipality rather than individual parishes) Digital PB was adopted in 2008 and was considered the only viable way of carrying out the experiment in a capital which also had a large floating population in the metropolitan area. From the outset PB in Lisbon therefore aimed to involve not only residents, but also everyone who studied or worked in the Portuguese capital.

Whereas in the first year of the experiment - in the two combined sets of sessions 1,732 people were registered on the Lisbon Council website (247 of whom submitted proposals), in the second year there were 6,958 registrations and 533 proposals, 293 of which were transformed into projects by technicians (after the exchange of almost 400 emails with the public employees involved) before electronic voting began (CML, 2009 and 2010). Between 2008 and 2009 the number of voters rose from 1,101 to 4,719 and the number of votes totalled 11,570 in 2010 . The profiles of the citizens involved in the debate and electronic voting (which in Lisbon involved a fixed annual sum of 5 million euros) remained similar throughout 2008 and 2009 - consisting mainly of residents in the capital (68\%), aged $26-45$, with a slight predominance of females (53\%) and average or high levels of education. The fact that the Council had organised a survey to assess PB, to which 2,121 people (approximately $30 \%$ of the participants) responded proved important, since as a consequence of the results certain new features were introduced into the 2011 PB session in the Portuguese capital, the most important of which was the abandonment of PB centred on proposals and discussion by electronic means only. ${ }^{6}$ In fact, from June 2010 onwards the tradition begun in 2007 of "decentralised meetings" in various parts of the city was reinstated and several specific meetings were added to enable citizens to submit proposals in person which would later be published on the Council website (using georeferencing to locate them in the areas of the city for which they were planned) and afterwards ranked by electronic voting. In 2010, in order to increase the involvement of citizens without access to the Internet or with little knowledge of IT, a "special PB bus" was also provided, equipped

\footnotetext{
${ }^{6}$ As cited in the "Collective view" subsection of the 2010 Assessment Report available on the CML webpage, "Citizens have stated that presenting proposals via the Internet only eliminates the possibility of consolidating a particular proposal for debate, since it makes this a very individualised action" (http://www.cmlisboa.pt/op/archive/doc/RelatoriodeAvaliacao_Sintese_OP2009_2010.pdf).
} 
with computers connected to the Internet and from which Council employees offered support for citizens. Meetings were organised with specific actors, such as the elderly and pupils from the local schools.

The ESPA 2009 prize awarded for PB in the German city of Cologne, in addition to the international recognition for PB in the Andalucian city of Malaga (governed by the Spanish Partido Popular) demonstrate that nowadays - particularly in larger cities - the use of ICT in PB procedures may extend beyond the mere provision of information or monitoring of processes (Allegretti, 2007). This does not mean that the process cannot generate new forms of exclusion, given that, presumably, the image of ICT as a powerful technological tool with a potentially elitist component in terms of access, determines a "syntax of use" centred on its "subordination" to the face-to-face aspects of PB cycles.

It is worth noting that this image may represent a projection of the fears of generations who are not fully at ease with technology, and this can inhibit dialogue with other groups (such as young people) for whom the language of new technology represents a friendly element and even a stimulus to engagement in public debate. It is not by chance that the majority of the municipalities in Sweden working on Participatory Budgeting with young people (in particular Örebro and Uddevalla) encourage Internet use as a means of increasing the numbers involved in the voting phase, and that others (as was the case in Haninge and Avesta), although more concerned to foster physical encounters between citizens, have constructed geo-blogs with the aim of boosting the multiplying potential of the debate on the net and the transparency, clarity, accessibility and attractiveness of the proposals presented, discussed and voted on by local residents. In 2009 the Swedish Association of Municipalities and Regions (SKL) went as far as constructing a "budget simulator"7 to stimulate new and richer debates on the organisation of municipal investments, both within local council meetings and amongst society in general, taking advantage of the strong support potential offered by the Internet.

Finally, it is worth mentioning the case of Vignola, in Italy, where new technologies were introduced into the PB process in a different form and did not favour articulation between real-time components and online voting. In this case, the same importance was accorded to real-time voting and online voting, and the result was that the winning project (a sports complex, i.e. a project that would attract the interest of young people) was approved by $60 \%$

\footnotetext{
"See the "IT-tools" session on the SKL webpage: http://www.skl.se/medborgardialog.
} 
of the electronic votes. This result translated into a disincentive to participate in actual meetings (particularly for those who felt that their active involvement in live meetings had been undervalued), to the extent that 2005 represented the first and last year in the life of PB in Vignola.

\section{The view from the other side}

The above examples show that, whilst it is not easy to unequivocally place PB (as an instrument of political innovation) within the context of the six models of democracy outlined by Held (2006), it is even more difficult to interpret the changes to the categories of PB that might be created by the presence of ICT. This is primarily because the incorporation of ITC within PB - which was more homogenous in the 1990s in terms of a "grammatical subordination" to an architecture constructed mainly on the basis of face-to-face debate nowadays reflects specific logics which, as the examples of Belo Horizonte and Lisbon demonstrate, envisage greater complexity and even paradigms of "parallel contemporaneity" or "instrumental primogeniture" in processes centred on the use of electronic means to create new participatory budgeting experiences in an era of low energy and little political faith.

The latter examples may help us explore a topic complementary to the one chosen as the focus of this article: the use of ITC within the context of participatory budgeting and its ability to promote more participatory forms of citizenship and democracy, depending on how the use of these tools is framed by the official bodies and institutions who initiate participatory processes, integrating them within the actual processes of participation and deliberation. This complementary topic - which opens up a whole new area for reflection refers to the exploration of the potential or problems which the use of ITC can create in the eyes of users or, in other words, citizens. Although such reflections are not central to the perspective of this article, it is worth referring to some themes that are emerging out of the abovementioned examples.

Belo Horizonte has gradually become receptive to the use of ICT to supplement years of experimentation with a predominantly face-to-face form of PB. Although no major problems have arisen, "Digital PB" has been subjected to heavy criticism from the popular movements involved in regional Participatory Budgeting, who see it as a wealthier competitor that is more open to manipulation by "hegemonic" social groups (Sampaio, 2010). The case of 
Vignola, in turn, reinforces the idea of competition between different arenas for participation and reveals the risks of not confronting and establishing an interconnection between the "deliberative phase" (in the Anglo-Saxon sense of discussion and exchange of opinions and rational arguments) and the decision-making phase, that is, voting for the priorities to be financed by public funds.

All the known examples of PB which have used ITC in the phase dedicated to proposals and the discussion of claims put forward by citizens demonstrate the difficulty of initiating debates using "cold methods," including cases (such as Roma XI or Lisbon) that have georeferenced popular proposals to facilitate chats and discussion on proposals and possible variations. The image that these virtual spaces offer to the navigator is that of an acritical accumulation of individual positions defined by strong convictions with little margin for flexible negotiation. At the same time (as would appear from the Report on the Lisbon 2010 PB cycle - see CML, 2011), the virtual space is perceived as a doubly moderated arena, and this lessens mutual trust between citizens and the local authority, given that the visible space for proposal and debate conveys an illusory neutrality behind which can be perceived the work of actors who not only summarise but also select some of the content sent by online contributors.

What took place in Lisbon in November 2009 may well explain the risks associated with this perception. In fact, after voting opened on the PB priorities to be included in the 2010 budget, some citizens protested strongly that their proposals had not been included in the list of projects to be put to the vote following technical, legal and financial feasibility studies by the Council's technical team. The protests could have led to a rapid loss of confidence in the entire PB process, given that the virtual space appeared to have been manipulated by unknown actors operating behind the scenes and able to change the voting lists in accordance with a "hidden agenda" which did not appear to reflect a fair and balanced attitude towards the different proposals. Fortunately, the Mayor understood how to take advantage of the crisis and prevent the entirely innocent actions of the back-office team (such as deleting proposals that were unclear or considered totally unfeasible) from being interpreted as acts of bad faith which threatened the legitimacy of PB. In the end the vote on the priorities was annulled and the voting period only reopened after the contested proposals had been reinstated and clarified through dialogue with their advocates. 
Without doubt, the good political use made of this moment of crisis conveyed the idea that the Council had a strong commitment to $\mathrm{PB}$, as demonstrated by the increase in the total number of votes cast in the second round. This ability to learn from mistakes was also evident in the fact that an amendment was introduced into the PB regulations stipulating a new "space designed to foster trust." With the aim of cleaning up the image of the webpage as a place subject to possible manipulation, an obligatory period was established (starting in October 2010) for the Council to receive criticisms and suggestions from local residents, after the proposals had been assessed for feasibility and before electronic voting commenced.

Although there are still no specific case studies on the subject, it is worth emphasising that the essentially "electronic" nature of PB in the years 2008 and 2009 did not pose many obstacles to the creation of a powerful organisational dynamic in Lisbon society, and that the "competition" between proposals/projects put up for vote was boosted by mobilising social groups, grassroots movements and some parishes in the city (such as Carnide, which had already experimented with PB within the scope of its powers since 2005). The opening up of live PB meetings in Lisbon to discuss investments for 2011 reinforced this social dynamism, and also served to familiarise the public with the full team of technicians (and political leaders) responsible each year for the organisation of the various phases of the process, thus establishing a more direct and "visual" form of contact between them and the participants.

As evidence of the central role played by the recently created meetings in the spread and ample growth of confidence in PB in Lisbon, and especially in reinforcing its deliberative aspect (which had been a very weak aspect of the site in previous years), it should be noted that - although the attendance at the meetings numbered around 400 , that is, a much smaller amount than the 12,681 registered on the webpage - 5 out of 7 of the approved proposals were presented at face-to-face meetings. ${ }^{8}$ At the latter events (unlike the procedure for the Lisbon PB webpage) only proposals that received at least $50 \%$ of the votes in favour from each work group were accepted. This method led to a greater convergence in the case of some proposals (in addition to debate and improvements through discussions involving those present at the meetings) in comparison with the website, where the

\footnotetext{
${ }^{8}$ Although the PB Report analysing the proposals for 2011 is still provisional, the numerical data was presented publicly by Councillor Graça Fonseca at a PB plenary session on 5 November 2010. The results presented at a Seminar in Aveiro on 12 November 2010 show that in this year in Lisbon 927 PB proposals were presented by 767 entities (492 in meetings) and 291 were converted into projects for subsequent voting.
} 
proposals emerged in the main on an individual basis. It is also interesting that proposals made by citizens on the basis of the electronic survey proposed by the Council suggested that, in future, the projects approved collectively as part of PB should be available for consultation on the site, as well as the time periods for their implementation (stipulated in the regulations as up to a maximum of 18 months).

Doubtless the method used in Lisbon - which makes the PB process no longer totally centred on ITC but based instead on a mixed architecture, investing in arenas for face-toface dialogue as its real driving force (and particularly of its deliberative component) - says a great deal about the long road that lies ahead to ensure that, in the eyes of users-citizens, electronic platforms are considered a trustworthy and reliable mediator in PB processes.

Thus, it is important that in the future there is serious consideration of issues such as: what type of experience of democracy and concept of citizenship is created amongst citizens through interventions involving ITC in PB? In processes that aim to use ITC to mediate in participation, how are the political skills needed by citizens to engage in the participatory and deliberative interplay and the technical skills needed to work with TIC linked? Furthermore, in the view of citizens, will the highly technical content of the central object of PB be considered an obstacle to significant use of other technical instruments (such as ICT)? And what precautions should be taken in future to gradually achieve a balance between the development of PB and the increased use of ICT?

\section{An open conclusion}

The aim of this article was to reflect on innovative links between representative democracy and participatory democracy in a scenario in which the challenges posed by the introduction of new technologies directed towards expanding the formal spaces of political intervention are added to these complex relationships.

As can be seen from this brief text, recourse to new technologies in participatory processes and political decision-making takes on very different forms. It can entail a limited inclusion - serving as an information tool or, at most, assisting in monitoring or debate - or, in certain cases, a more advanced use of the resulting potential, by assisting actual decisionmaking processes. The cases presented here are representative of these different configurations, highlighting clear examples of the "subordinated" and "coordinated" use of ICT in democratic processes. The former is the result of applying hybrid or complementary 
processes that combine forms of face-to-face interaction with different technological instruments. A broader comprehension of electronic democracy leads to the consideration that it is not simply governments that can act as its agents, but also individuals and organisations within society. If, on the one hand, governments can use ICT as a means of increasing participation and legitimising decisions, society can also use it as a means of accessing the relevant information to enable it to organise politically and mobilise around issues it considers relevant. On the other hand, government use of technologies can strengthen the technocracy specialising in information systems (or infocracy), which can acquire importance and independence in relation to the government itself (Hacker and Djik, 2000).

As Jasanoff (2003) demonstrates, the affirmation in political literature that the quality of solutions directed towards solving problems depends on the adequacy of their initial design has become an almost undeniable truth. Thus, if an issue is too narrowly, or too vaguely, or simply erroneously framed, the solution will reveal the same problems (id.). What the examples presented here show is that the framing of the problem is as important as the actual process. If we are faced with interactive processes, those who take part in them will ultimately be able to redefine the design and adapt it to the needs that emerge throughout the actual process. The case of the changes that took place in PB in Lisbon between 2009 and 2010 is a very clear example of this.

As a participation technology, PB is in a position to configure processes which, instead of reproducing the separations existing in the various democratic models - the separation between representatives and those represented and between specialists and the lay public help promote cognitive citizenship. ${ }^{9}$ This requires the involvement of citizens, endowing them with decision-making capacities in processes involving technical dimensions and operating in the sphere of state intervention, in an area traditionally seen as the preserve of state regulation. However, neither the reinforcement of democracy nor the contribution to citizen empowerment can be attained by introducing ICT. In processes such as the ones presented here - which combine social and material technologies - the potential for empowering and involving citizens appears to be more easily achieved in face-to-face PB, in

\footnotetext{
${ }^{9}$ In countries such as South Korea, this aspect has become central to the construction of PBs, always accompanied by "PB schools" which aim to train individual participants as the processes develop (see Sintomer, Herzberg and Allegretti, 2010).
} 
which the participants have to master the proceedings and regulations in order to participate. In cases in which the use of ICT is prioritised, participation may be reduced to the use of a particular technology (useful for presenting sets of options and individual preferences), since participants do not have to know how the relevant technologies work (telephone, the Internet, etc.) in order to use them. ${ }^{10}$ In short, it is not enough to extend the process democratically in terms of participation, it is also necessary to democratise it in terms of knowledge.

One of the conditions for securing wider citizen participation is the provision of ample and varied forms of access, including the understanding and use of these resources. A second condition concerns making the necessary information available, to ensure not only the quality of participation in the decision-making process, but also its transparency. A third condition is related to the diversity of means and processes which make participation viable, including the different ways of acquiring information, of expressing opinions and deliberating, especially on the part of those who will be affected by decisions. A fourth condition concerns the government's commitment to carrying out the decisions made in processes of this nature.

In this regard, the support afforded by ICT may doubtless prove very relevant in terms of transparency and restoring confidence in institutions, as demonstrated by PB in Porto Alegre, Sevilha, Malaga and Sesimbra (which constructed web applications to monitor the execution of PB approved projects). Once again, however, the case of Belo Horizonte (which has created local resident committees - Comforças - to monitor the implementation phases of projects approved by Participatory Budgeting), leads us to reflect on the indispensible overall value of investing in face-to-face operations, given that the internal dialogue of PB monitoring committees can be transformed into something that extends beyond simple transparency and helps create the capacity for critical control and new arenas for collective understanding of complexities.

Translated by Sheena Caldwell Revised by Teresa Tavares

\footnotetext{
${ }^{10}$ A situation which Latour (1999) characterises as the result of the process of 'black boxing', referring to the fact that when technologies operate efficiently the scientific and technological work is invisible. Paradoxically, the more technologies feature in our everyday lives, the more opaque and hidden they become.
} 


\section{References}

Abers, Rebecca (2000), Inventing Local Democracy. London: Lynne Rienner Publishers.

Addison, Tony; Heshmati, Almas (2003), The New Global Determinants of FDI Flows to Developing Countries: The Importance of ICT and Democratization. Helsinki: UNU/WIDER.

Allegretti, Giovanni (2003), Autoprogettualità come paradigma urbano. Firenze: Alinea.

Allegretti, Giovanni; Secchi, Michelangelo (2007), "Les Budgets Participatives (BP) en Italie: une géographie en changement continu," Territoires, 482, September. Paris.

Allegretti, Giovanni (2007), "Knowledge City and Citizens Knowledge: Which Help from IT to Participatory Process? Examples from Some Participatory Budgeting Experiences," paper presented at the colloquium "Knowledge Cities. Future of Cities in the Knowledge Economy," Shah Alam, Malaysia, 16-19 July.

Allegretti, Giovanni (2009), "Giustizia sociale, inclusività e altre sfide aperte per il futuro dei processi partecipativi europei," in Umberto Allegretti (ed.), Democrazia Partecipativa. Esperienze e prospettive in Italia e in Europa. Firenze: Firenze University Press.

Allegretti, Giovanni; Herzberg, Carsten (2004), El 'retorno de las carabelas'. Los presupuestos participativos de América Latina en el contexto europeo. Amsterdam/Madrid: TNI Briefing Series.

Arnstein, Sherry (1969), "A ladder of citizen participation," Journal of the American Institute of Planners, 35, 216-224.

Bannister, Frank; Walsh, Neasa (2002), "E-Democracy: Small is Beautiful?" in Dan Remenyi (ed.), Second European Conference on E-Government. Reading, UK: Author's edition (available in Google Books).

Bobbio, Luigi (2006), "Dilemmi della democrazia partecipativa," Democrazia e Diritto, 4, 11-26.

Borghi, Vando (2005), La sperimentazione del Bilancio Partecipativo nel Comune di Modena. Report di monitoraggio: l'avvio della sperimentazione e la fase di ascolto strutturato. Consulted on 04.12.2010 at http://www.comune.modena.it/viapervia/web/documenti-e-convegni/relazionevando-borghi.

Cabannes, Yves (2004); “72 Frequently Asked Questions about Participatory Budgeting”, UN/Habitat. Consulted on 04.12.2010 at http://www.internationalbudget.org/themes/PB/72QuestionsaboutPB.pdf.

Callon, Michel; Lascoumes, Pierre; Barthe, Yannick (2001), Agir dans un monde incertain: essai sur la démocratie technique. Paris: Seuil.

CML - Câmara Municipal de Lisboa (2009), Orçamento participativo 2009. Relatórios finais. Lisboa: Câmara Municipal de Lisboa, March 2010.

CML - Câmara Municipal de Lisboa (2010), Orçamento participativo 2010. Relatório de Avaliação. Lisboa: Câmara Municipal de Lisboa, March.

CML - Câmara Municipal de Lisboa (2011), Orçamento participativo 2011. Relatório de Avaliação. Lisboa: Câmara Municipal de Lisboa, January.

Chavez, Daniel (2007), paper presented at the "Jornadas Internacionales sobre Presupuestos Participativos." Málaga, Spain, 28-31 March.

Dagnino, Evelina; Olvera, Alberto J.; Panfichi, Aldo (2006), "Para uma outra leitura da disputa pela construção democrática na América Latina," in Evelina Dagnino, Alberto J. Olvera and Aldo 
Panfichi (eds.), A disputa pela construção democrática na América Latina. São Paulo: Paz e Terra. Campinas: Unicamp.

Deiber, Ronald J. (2003), "E-Democracy: Current Trends and Future Prospects." Consulted on 04.12.2010 at http://www.law-lib.utoronto.ca/investing/reports/rp19.pdf.

Graft, Paul; Svensson, Jörgen (2006), “Explaining E-Democracy Development: A Quantitative Empirical Study," Information Polity, 11, 123-134.

Hacker, Ken; Djik, Jan (2000), Digital Democracy, Issues of Theory and Practice. London: Sage Publications.

Held, David (2006), Models of Democracy, $3^{\text {rd }}$ ed. Palo Alto, CA: Stanford University Press/Polity Press.

Horrocks, Ivan; Prachett, Lawrence (n.d.), "Electronic Democracy: Central Themes and Issues," Club of Amsterdam. Consulted on 04.12.2010 at http://www.clubofamsterdam.com/content.asp?contentid=228.

Jasanoff, Sheila (2003), "Technologies of Humility: Citizen Participation in Governing Science," Minerva, 41(3), 223-44.

Latour, Bruno (1999), Pandora's Hope: Essays on the Reality of Science Studies. Harvard: Harvard University Press.

Nunes, João Arriscado (2006), "Da democracia técnica à cidadania cognitiva: a experimentação democrática nas sociedades do conhecimento," working paper. Coimbra: Centro de Estudos Sociais

Ravazzi, Stefania (2007), Civicrazia. Quando i cittadini decidono. Roma: Aracne.

Ring, Nicole; Walden, Brian (2003), "White Paper on E-Democracy in Potsdam." Consulted on 04.12.2010 at http://brianwalden.com/writing/final.doc.

Sampaio, Rafael (2010), "Participação e deliberação na internet: um estudo de caso do Orçamento Participativo Digital de Belo Horizonte." Master's Thesis in Media Studies. Belo Horizonte: UFMG.

Santos, Boaventura de Sousa; Avritzer, Leonardo (2002), "Introdução: para ampliar o cânone democrático," in B. de Sousa Santos (ed.), Democratizar a democracia: os caminhos da democracia participativa. Rio de Janeiro: Civilização Brasileira.

Schmidt, David (2000), "A 'desidiotização' da cidadania. A dimensão pedagógica do Orçamento Participativo." Paper presented at the seminar $O$ OP visto pelos seus pesquisadores. Porto Alegre: PMPA.

Sintomer, Yves; Allegretti, Giovanni (2009), I bilanci partecipativi in Europa. Nuove sperimentazioni democratiche nel vecchio continente. Roma: Ediesse.

Sintomer, Yves; Herzberg, Carsten; Allegretti, Giovanni (2010), World Report on Participatory Budgeting. Bonn: InWent (version in German and English).

Sintomer, Yves; Herzberg, Carsten; Röcke, Anja (2005), Participatory Budgets in a European Comparative Approach. Perspectives and Chances of the Cooperative State at the Municipal Level in Germany and Europe. Vol. II (Final Report - documents). Berlin: Centre Marc Bloch.

(Also available at http://www.buergerhaushalteuropa.de/documents/Volumen_zwei_Endbericht_Buergerhaushalt_Europa5.pdf). 